\title{
寺田哲郎・江野窪文章両氏の「積層状電気 絶縁紙の真空乾燥過程」゙に対する討論
}

日立製作所 堤 泰 行

真空乾燥過程に対する本論文の考え方および基本式 (6)书よび (7) は，物理的にきわわて無理のない妥 当なるのと思われます。しかし，真空乾燥の過程で絶 縁物内部の圧力 $P(\mathrm{mmHg})$ が時間上と屯に変方る傾 向は，第 10 図に示されているように実験值と計算值 が良く一致していますが，その圧力の絶対值が実測犆 $19 \mathrm{mmHg}$ なのに，100 mmHg を用いて計算している のはよ゙のような理由によるものでしょうか。100 mm. $\mathrm{Hg}$ 加ら乾燥を始力る場合は，19 $\mathrm{mmHg}$ 加ら乾燥を 始める場合に比べて第 10 図から明らかなように, 乾燥 時間は約 2 㥉もかかりますので，このような誤差の大 きな計算方法は実用的ではありません。筆者も以前， (6)，(7)式と全く同じ考えに基づきプレスボードを 用いて，乙の理論の検証在試みたことがすりすすが， 満足すべき結果が得られませんでした。本論文では指 摘されていませんが，絶緑物加ら水分加蒸発する際， 蒸発潜熱を奪い温度が大幅低下しますので，一般的 には（6），(7) 式の上うな恒温という条件は満たさ れません。

第1図に示すように，3.2 $\mathrm{mm}$ 厚のプレスボードの 両側化 $10 \mathrm{~mm}$ 厚の鉄板を付け, 温度の変化を小さく して実験しました。真空乾燥時化出される水分をド ライアイストラップで補等すると第2罒のような結果 が得ら机ました。一方，とのプレスボードについて

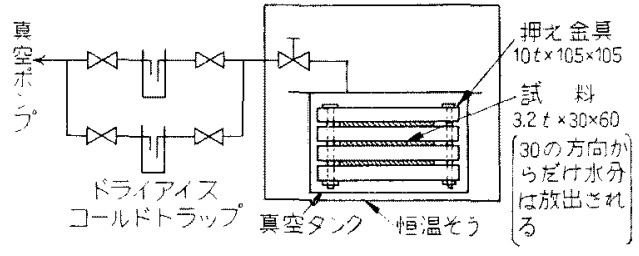

第 1 图真䛼乾燥実験装置

Fig. 1. Shematic diagram of experimental apparatus.

堤 禁行：正虽，日支整作所

*: Vol. $92-A$, No. 5, p. 207 揭赫

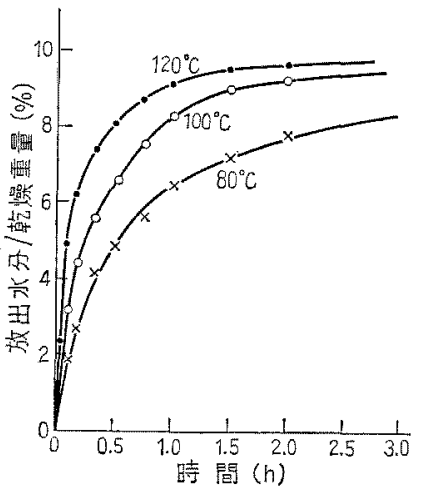

第 2 図真空乾燥の乾燥特性（実測值） Fig. 2. Experimental vacuum drying characteristics.

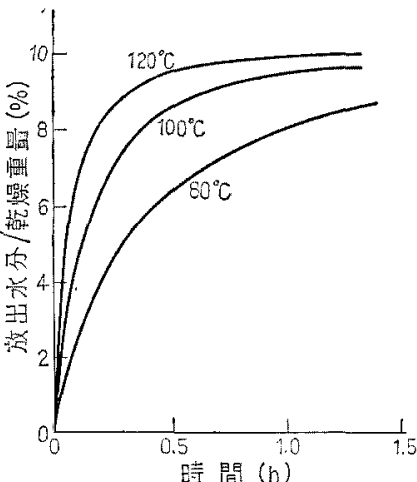

第 3 图真空乾燥の乾燥特性 (計算値)

Fig. 3. Calculated vacuum drying charceteristics.

は，原文とはぼ同じような方法で透気度を測定し，分 子流領域に打ける透気度の值を用いて（6)，（7）式 を解き，各点の水蒸気压の变化加ら，（1）式により 各点の水分变化を求め，乙れを緦縁物全体について皘 分し排出水分を計算しますと第 3 四の結果が得られま した。なお，筆者のプログラムでは，初期条件として 絶縁物比含まれる初期水分を入れるようになっていま 
す。

第 2 図々第 3 図上を比較しますと，乾澡時間の絶対 值は約 2 倍だけ違いがありますが，おし時間を倍だけ シフトす机ば時間㔚るいは温度による排出水分の様子 は良く一致します。したがって，筆者は（6）项拉よ び（7）式は基本的には正しいが，乾燥時間の絶対倠 在求めるには，さらに何らかのくふうが必要ではない
かと考えました。原文老抹見しましたところ，箁者の 結果と全く同じく，時間を倍だけシフトすれば実験值 と計算儃之が一致するという結果であり，本理諭はま だ完成の域に㤬していないと思います。時間をシフ トしないで完寒测值之計算值之を一政させるに注，今 後よ゙のような点を楅討すべきでょうか。

\section{堤 泰行氏の討論に対する回答}

\author{
古河電気工業株式会社 \\ 古河需欲工業株式会社
}

堤氏の論旨の第一は，初期の王力 $P$ が実騒では 19 $\mathrm{mmHg}$ であるのに，計算には $100 \mathrm{mmHg}$ を用いる のはなぜか，ということです。

乾煤の過程では，経過時間は相対的な索ので古りま す。すな放吉，第 1 图で $P_{0}$ が初期の含水率に対応す る蒸気圧であれば， $T_{1}$ が時間の起点になり， $P_{0}^{\prime}$ が 初期値だとすれば $T_{1}{ }^{\prime}$ 少起点となります。しかし，い ずれも乾噪しようとする材質の温度による吸着特性上 遥気度加決まる一つの線上をたどるという考えに基 ふいて乩ります。如的れが知りたいのは，任意心初 期值から以降，時間とともにどのように $P$ が隇少し ていくか，というこ上ですので， $T_{1}$ は任意の初期水 分に対応して定まり，時間軸上で一定数在加元，䒠際 時間に対応させればよいわけです。ここで解析に便利 なように，この曲線が $\log -\log$ 目盛で直線よなる值, すなわち $P_{0}=100 \mathrm{mmHg}$ では $T_{1}=0.3$ を選んで図 示したわけです。計算上は $P_{0}$ は 100 でも50で屯 さしつかえないのですが，計算は透気度一定の饭定の すとに行なっていますから，その範围で適用するのか 妥当です。式の上からは，T檔分定数であります。

論旨の第二は，恒温の条件は実際上一般には满足さ れない点です。

ご指摘のように，含水率 $5 \sim 10 \%$ の絓学乾燥温度に 加熱して加貢空引を始めると温度は $10^{\circ} \mathrm{C}$ 程度も低 下します。乙の場合は温度の回復後, 式に上ると考元 ざるをえません。電力ケーブルの場合は澊体に通電す ることによって所定温度に保ちますので, 定常状態に 到達した以㣪（6)，（7）式適用します。所定温度 になるまでの時間は加熱方法，手段により異なります

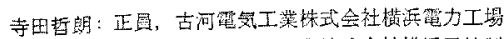

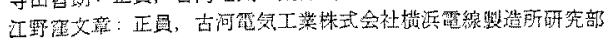

Vol. $92-A$, No. 12

寺田哲 朗 江野窪 文 章

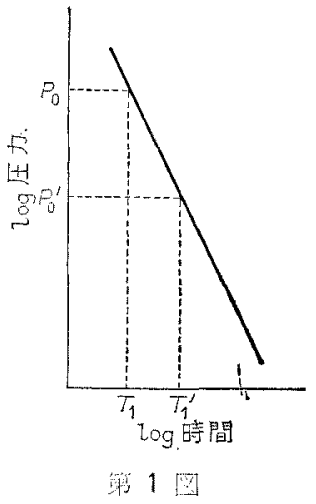

Fig. 1.
ので，所定温度になった とき花眭間の起点しすれ ばよいかけです。

諭旨の第三は，堤正の 実綮に基ついいて理論と実

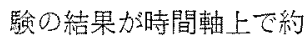
2 倍遠う点ですが，第 1 図ではプレスボードの板 面沿いの方向に水分が放 出さ扎る構成になってい ます。鉄板とプレスボー ドの尿間を氷蕉気力゙通る ように見寡けますが、こ のはかにプレスボード自体の厚さ方向の透気度が關与 しているのではないかと思われました。

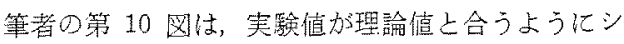
フトしたのではなく，雨者が $\log -\log$ スケール上で直 線己なる $T_{1}$ 扰よび $t_{1}$ の值圭選び， $T+T_{1}$ および

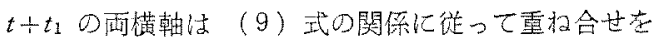
したあのです。

则上ように，堤氏が疑問とされた $P$ 朝およで $T$ 䩜の決方仗，筆者らの解析法の一般性定間う点，核 心にふれたむのであります。

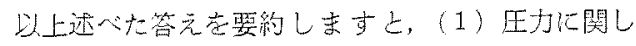
ては任意の压力の起点学のの時間の起点にすればよ い。(2) 時間に対しては (9) 式によって時間の变撸 をす机ば，絶縁曆の異なるむのも一つの時間 $T$ で报

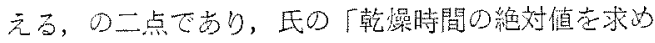

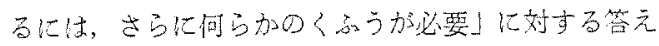
にる场っていると考无石次第てす。 